\title{
Role of Competency Development Practices in Achieving Organizational Commitment
}

\author{
Effulgence \\ Vol. 16 No. 1 \\ January - June, 2018 \\ Rukmini Devi Institute of Advanced Studies \\ E-mail : effulgence@rdias.ac.in, Website : www.rdias.ac.in \\ http://effulgence.rdias.ac.in/user/default.aspx \\ https://dx.doi.org/10.33601/effulgence.rdias/v16/i1/2018/14-23
}

\section{Dr. Shevata Singhal ${ }^{1}$}

\begin{abstract}
The positive effects of Organizational Commitment (OC) have been well documented in management literature. Various Human Resource Management Practices affect the commitment of employees in an organization. An organization that invests in its human capital and grants employees sufficient resources and opportunities to improve their skills (competence development) has a greater likelihood of developing a higher level of commitment among its employees (Paré, G. E Tremblay, M. 2004). Such practices make the employees feel significant, responsible and free to optimally channel their creativity and competencies. This study takes initiative to find out the role of competency development practices in achieving organizational commitment. The target population of this study was engineers of private sector in NCR. The sample size of this study is 392. Regression analysis and ANOVA is used to test the hypothesis. Results of this study proved that competency development practices play a significant role in achieving organizational commitment.
\end{abstract}

Keywords: Organizational Commitment, Competency Development Practices, HR, Employees.

\section{INTRODUCTION}

$\mathrm{I}$ n today's extremely competitive international economy, rising and retaining capable employees is a main challenge for HR executives. Organizational commitment is the backbone of the modern HRM philosophy (Shahnawaz, M. G. \& Juyal, R. C. 2006). Employee's long term relationship with the organization and their intention to stay in it along with firm faith in the objectives and goals of his/her organization, complied by dedicated attempt attain these objectives and goals (Steers, R. M. 1977; Mowday, R. T. et al 1979). The positive effects of Organizational Commitment (OC) have been well documented in management literature. As organizations recognize the competitive advantage that can be gained through human resources practices. Various Human Resource Management Practices affect the commitment of employees in an organization. Further research studies have shown that Organizational Commitment must be differentiated from job satisfaction: Organizational Commitment controls and guides the person in the

1. Assistant Professor, School of Management Studies, Ansal University, Gurgaon, shevata.mmgt@gmail.com 
organization, whereas job satisfaction results from an individual relation to work, Organizational Commitment shows the strength of the commitment which a working person feels for the organization he or she works in.

Meyer, J. P. \& Allen, N. J. (1984) initially viewed Organizational Commitment as two dimensional namely, affective and continuance. Meyer, J. P. \& Allen, N. J. (1984) defined the first dimension, namely affective commitment as "positive feelings of identification with, attachment to and involvement in the work organization", and they defined the second dimension, namely continuance commitment as "the degree to which employees feel committed to their organization by virtue of the costs that they feel are associated with leaving". After further research, a third dimension, namely normative commitment is added by Allen, N. J. \& Meyer, J. P. (1990).

Allen, N. J. \& Meyer, J. P. (1990) defines normative commitment as "the employee's feelings of obligation to remain with the organization". Consequently, the concept Organizational Commitment is described as a tri-dimensional concept, characterized by the affective, continuance and normative dimensions (Meyer, J. P. \& Allen, N. J. 1991). In this study all the three components of organizational commitment given by Allen, N. J. \& Meyer, J. P. (1990) is considered for the purpose.

Thus, drawing from above paragraphs it can be inferred that committed employees contribute a lot in the organization and it's functioning by operating in the limelight of achieving the organization's goals. Likewise, personnel who are steadfast for their organization are happy and delighted to be a part of it, have confidence in it and feel good about the same (Feinstein, A. H. \& Vondrasek, D. 2001). Though a large amount of work has been written and talked about of Organizational Commitment but still there exists the great amount of confusion on how the factors associated in achieving the development of the Organizational Commitment. Further, Human resources management practices such as empowerment, fair reward practices, recognition, competency development, information sharing practices, empowerment etc. have been stated as the organizational factors that help in achieving the Organizational Commitment (Maheshwari, S. et al 2007; Shahnawaz, M.G. \& Juyal, R. C. 2006; Boglera, R. \& Somech, A. 2004, Soltani, M. 2015) but few studies have taken competency development practices as a factor helpful in achieving Organizational Commitment of engineers of private sector in NCR. Competency development practices (e.g. responsibilities as per employees' interest, coaching and training, mentoring, accessibility of resources to develop new competencies, encouragement to apply innovative work practices etc) have been considered in this study.

Competency development practices communicate to the employees that organizations give emphasis to Human Resource and consider them as valuable assets and consider that investment in Human Resource is to gain competitive advantage and helpful in maintaining a long-term relationship between the employees and the organization. This study on Organizational Commitment of private sector has focused on engineers of NCR. The study of employee commitment should be important to private sector involved in huge production and a great contribution in GDP and the community as a whole. This study of Organizational Commitment will especially be relevant to engineers of private sector in NCR. Thus this study will try to find out the role of Competency Development Practices in achivving Organizational Commitment of engineers of private sector in NCR.

\section{OBJECTIVE OF THE STUDY}

This study tried to find out the role of Competency development practices in Achieving organizational commitment. So, on the basis of the above discussion the objectives of this study are as follows: -

1) To study the effect of Competency Development Practices on Affective Commitment. 
2) To study the effect of Competency Development Practices on Normative Commitment.

3) To study the effect of Competency Development Practices on Continuance Commitment.

\section{REVIEW OF LITERATURE}

Competence was a fuzzy concept as described by Van der Klink, M. R. \& Boon, J. (2003). Due to lack of universal definition and uncertainty about the concept in literature these authors support their statement. To make sure a complete coverage of the word, scholars opt for an extensive definition of competencies (Delamare Le Deist, F. \& Winterton, J. 2005). Spencer, L. M. \& Spencer, S. M. (1993), define competency as: "an underlying characteristic of an individual that is causally related to criterionreferenced effective and/or superior performance in a job or a situation".

In this study competency development is taken from an organizational view point. In this viewpoint, scholars explain competency development as a significant characteristic of the wider defined conception of competency management (Heinsman, H. et al 2006). Heinsman, H. et al (2006); describe competency management as "an important human resource tool that is often used within organizations to guide human resource practices such as selection, assessment, career management, employee development, and performance appraisal". Additional on the work of Forrier, A. et al (2009), competency development was defined as: "an important feature of competency management which encompasses all activities carried out by the organization and the employee to maintain or enhance the employee's functional, learning and career competencies".

Concentrating on the continuous development of employee's competencies is necessary for organizations, as it gave organizations an opportunity to gain competitive advantage over its competitors (Tampoe, M. 1994). Also emotional attachment with the organization in the form of affective commitment can be build up by HRM policies (Jeet, V. and Sayeeduzzafar 2014, Hassan, S. and Mahmood, B. 2016). The management literature growingly acknowledged the importance of competency development practices in enhancing the employees commitment (Zaitouni, M. et al 2011; Paré, G. \& Tremblay, M. 2004; Sawalha, N. et al 2012; Paré, G. et al 2001; Colbert, A. E. \& Kwon, I. G. 2000). Another study conducted on doctors proved that low concern for people development and poor training climate (competency development practices) results in lower commitment, and frustration among the doctors (Maheshwari, S. et al 2007). So today's work environment competency development practices has become a vital strategic management tool.

The important function of competency development in enhancing the achievement of employees and organizations has attract the awareness of practitioners leading them to set up competency development as an essential element of their human resource practices (Delamare Le Deist, F. \& Winterton, J. 2005; Lawler, E. E. 1994). In the present day turbulent reality, there is a need to develop industry specific competency development practices to remain competitive and to develop committed workforce. As a result, in today's organizations the use of competencies within human resource management has become pervasive.

Competence development practices i.e. opportunities given by HR Management to employee to enhance their skills (e.g. mentoring, training, job rotation programs etc) communicate to employees that the organization considers human resources to be a competitive advantage (Schwochau, S. et al 1997), and that it was looking for to set up a strong bond with them (Tsui, A. S. et al. 1995; Guptill, B. 1998; Agarwal, R. \& Ferratt, T. W. 1999). Competence development practices are all activities which invest in human capital and give employees with the required resources and opportunities to enhance and develop their skills, enabling them to work in an environment that 
promotes career development and initiative-taking (Zaitouni, M. et al 2011). An organization that invests in its human capital and grants employees sufficient resources and opportunities to improve their skills (competence development) has a greater likelihood of developing a higher level of affective commitment among its employees (Paré, G. \& Tremblay, M. 2004). Such practices make the employees feel significant, responsible and free to optimally channel their creativity and competencies. These Researchers proved that Commitment and intention to stay in the organization occur when HR practices produce in them a feeling of autonomy and competence. This study takes initiative to find out the role of competency development practices in achieving organizational commitment.

\section{RESEARCH METHODOLOGY}

Research Design of this study was descriptive because this study is based on the hypothesis testing using various statistical tools. Data were collected from the engineers of private organizations in NCR. Questionnaire was used to collect the primary data in this study. Responses for commitment and competency development practices were collected using Likert scale $(1=$ Strongly Disagree to $5=$ Strongly Agree). Six item scale of Paré, G. \& Tremblay, M. 2000 was used for competency development practices and 15 item scale of Allen, $\mathrm{N}$. J. \& Meyer, J. P. (1990) was used for Organizational commitment. These scales were modified after pilot study so an adopted and modified scale was used for the study. Cronbach's alpha reliability test was used to test the reliability of the scale. The reliability coefficient of the organizational commitment scale of 15 items came out to be 0.879 . KMO value of organizational commitment scale was 0.830 which is a measure of Sampling Adequacy. The reliability coefficient of competency development practice scale of 6 items was 0.878 . To test the hypothesis simple linear regression and ANOVA was used using SPSS 16.

\section{Sample Design:}

The size of the population used in this study was infinite i.e. the actual size of the population was not known. As the population was not known in this study so the convenience sampling method was used. The sample size used in this study was 392 which is appropriate as per the rule and calculation. In this research, the engineers working in NCR was taken for study.

\section{Hypothesis}

Accordingly, the following hypotheses have been formulated for this study as: -

HO1: There is no significant role of Competency Development Practices in achieving Affective Commitment.

HO2: There is no significant role of Competency Development Practices in achieving Normative Commitment.

Ho3: There is no significant role of Competency Development Practices in achieving Continuance Commitment.

\section{ANALYSIS AND INTERPRETRATION}

The following tables show the result of the first Hypothesis. Model Summary, ANOVA and Coefficient tables have been given below to test the first hypothesis: 
Table No. 1: Model Summary ${ }^{\mathrm{b}}$

\begin{tabular}{|c|c|c|c|c|}
\hline & & & Adjusted R & Std. Error of the \\
Model & $\mathbf{R}$ & R Square & Square & Estimate \\
\hline 1 & $.497 \mathrm{a}$ & .247 & .245 & .74265 \\
\hline
\end{tabular}

a. Predictors: (Constant), Competency Development Practices

b. Dependent Variable:Affective Commitment

Table No. 2: ANOVA ${ }^{\mathrm{b}}$

\begin{tabular}{|c|c|c|c|c|c|c|}
\hline \multicolumn{2}{|c|}{ Model } & Sum of Squares & df & Mean Square & $\mathbf{F}$ & Sig. \\
\hline 1 & Regression & 70.384 & 1 & 70.384 & 127.618 & $.000^{\mathrm{a}}$ \\
\hline & Residual & 215.095 & 390 & .552 & & \\
\hline & Total & 285.480 & 391 & & & \\
\hline
\end{tabular}

a. Predictors: (Constant), Competency Development Practices

b. Dependent Variable:Affective Commitment

Table No. 3: Coefficients ${ }^{a}$

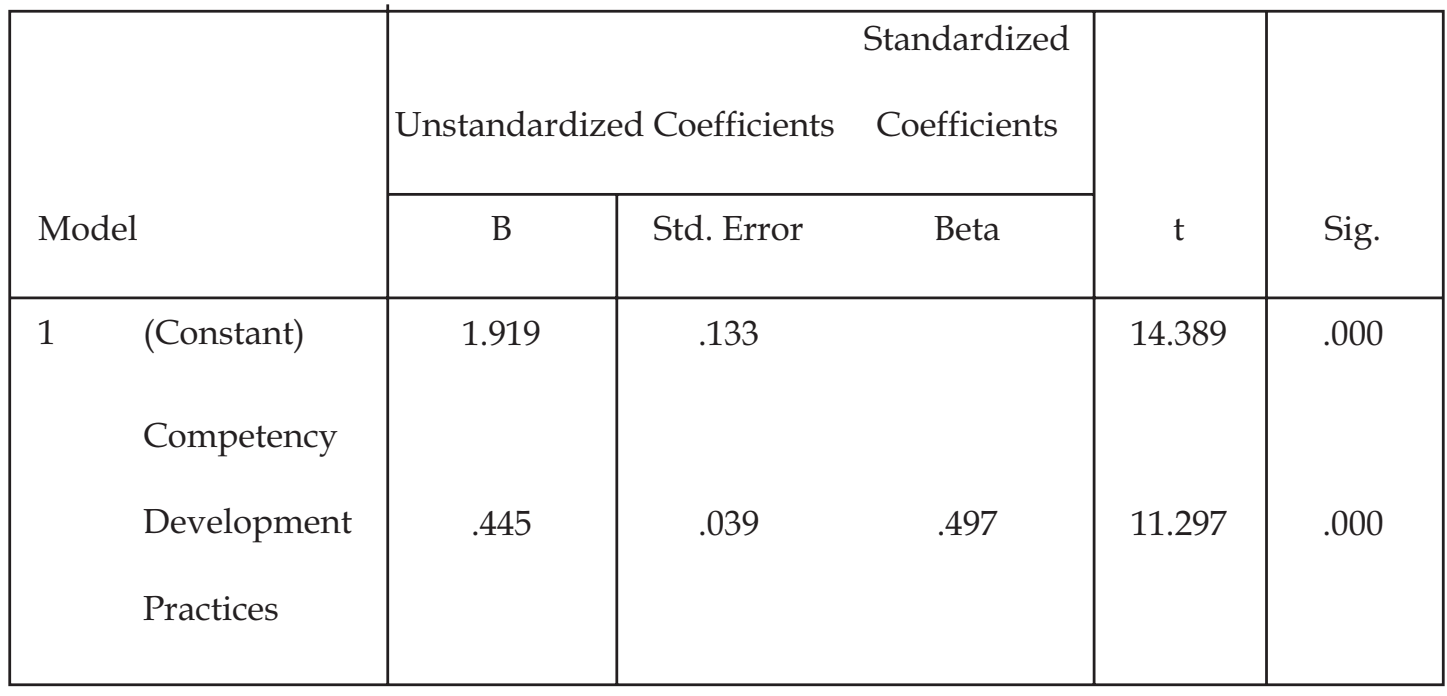

a. Dependent Variable : Affective Commitment 
Affective Commitment was entered as dependent variable and Competency Development Practices as Independent Variable in Model 1. The $\mathrm{R}$ value of this model is 0.497. The outcome of HO1 was that 'Competency development Practices' does indeed have a significant role in achieving Affective Commitment. The regression analysis showed 'Competency Development Practices' to be significant at the 0.000 level, which is lower than the 0.05 confidence level of this study. This result rejects the null hypothesis and concludes that "There is a significant role of Competency Development
Practices in achieving Affective Commitment". This finding is consistent with other researchers (Zaitouni, M. et al 2011; Paré G. \& Tremblay, M. 2004; Paré G. et al 2001) they found a significant relationship between Competency Development Practices and Affective Commitment.

The following tables show the result of the second Hypothesis. Model Summary, ANOVA and Coefficient tables have been given below to test the second hypothesis:

Table No. 4: Model Summary ${ }^{\mathrm{b}}$

\begin{tabular}{|c|c|c|c|c|}
\hline Model & $\mathrm{R}$ & R Square & $\begin{array}{c}\text { Adjusted R } \\
\text { Square }\end{array}$ & $\begin{array}{c}\text { Std. Error of the } \\
\text { Estimate }\end{array}$ \\
\hline 2 & $.477^{\mathrm{a}}$ & .228 & .226 & .68712 \\
\hline
\end{tabular}

a. Predictors: (Constant), Competency Development Practices

b. Dependent Variable: Normative Commitment

Table No. 5: ANOVA

\begin{tabular}{|ll|c|c|c|c|c|}
\hline \multicolumn{2}{|l|}{ Model } & Sum of Squares & $\mathrm{df}$ & Mean Square & $\mathrm{F}$ & Sig. \\
\hline 2 & Regression & 54.242 & 1 & 54.242 & 114.886 & $.000^{\mathrm{a}}$ \\
& Residual & 184.132 & 390 & .472 & & \\
Total & 238.374 & 391 & & & \\
\hline
\end{tabular}

a. Predictors: (Constant), Competency Development Practices

b. Dependent Variable: Normative Commitment

Table No. 6: Coefficients ${ }^{a}$

\begin{tabular}{|c|c|c|c|c|c|c|}
\hline & & Unstandar & Coefficients & $\begin{array}{c}\text { Standardized } \\
\text { Coefficients }\end{array}$ & & \\
\hline & & B & Std. Error & Beta & $t$ & Sig. \\
\hline 2 & $\begin{array}{l}\text { (Constant) } \\
\text { Competency } \\
\text { Development } \\
\text { Practices }\end{array}$ & $\begin{array}{r}2.139 \\
.390\end{array}$ & $\begin{array}{l}.123 \\
.036\end{array}$ & .477 & $\begin{array}{l}17.327 \\
10.719\end{array}$ & $\begin{array}{l}.000 \\
.000\end{array}$ \\
\hline
\end{tabular}

a. Dependent Variable: Normative Commitment 
Normative Commitment was entered as dependent variable and Competency Development Practices as Independent Variable in Model 2. The $\mathrm{R}$ value of this model is 0.477. The outcome of HO2: was that 'Competency development Practices' does indeed have a significant role in achieving Normative Commitment. The regression analysis showed 'Competency Development Practices' to be significant at the 0.000 level, which is lower than the
0.05 confidence level of this study. This result rejects the null hypothesis which concludes that "There is a significant role of Competency Development Practices in achieving Normative Commitment".

The following tables show the result of the third Hypothesis. Model Summary, ANOVA and Coefficient tables have been given below to test the third hypothesis:

Table No. 7: Model Summary

\begin{tabular}{|c|c|c|c|c|}
\hline Model & $\mathrm{R}$ & R Square & Adjusted R Square & $\begin{array}{c}\text { Std. Error of the } \\
\text { Estimate }\end{array}$ \\
\hline 3 & $.184^{\mathrm{a}}$ & .034 & .031 & .76286 \\
\hline
\end{tabular}

a. Predictors: (Constant), Competency Development Practices

b. Dependent Variable: Continuance Commitment

Table No. 8: ANOVA $^{\mathrm{b}}$

\begin{tabular}{|ll|c|c|c|c|c|}
\hline \multicolumn{2}{|l|}{ Model } & Sum of Squares & df & Mean Square & F & Sig. \\
\hline $3 \quad$ Regression & 7.928 & 1 & 7.928 & 13.623 & $.000^{\mathrm{a}}$ \\
& Residual & 226.960 & 390 & .582 & & \\
Total & 234.888 & 391 & & & \\
& & & & & \\
\hline
\end{tabular}

a. Predictors: (Constant), Competency Development Practices

b. Dependent Variable: Continuance Commitment

Table No. 9: Coefficients ${ }^{a}$

\begin{tabular}{|c|c|c|c|c|c|c|}
\hline & & Unstandar & Coefficients & $\begin{array}{c}\text { Standardized } \\
\text { Coefficients }\end{array}$ & & \\
\hline & & B & Std. Error & Beta & $\mathrm{t}$ & Sig. \\
\hline 3 & $\begin{array}{l}\text { (Constant) } \\
\text { Competency } \\
\text { Development } \\
\text { Practices }\end{array}$ & 2.596 & .137 & .184 & 18.947 & .000 \\
\hline
\end{tabular}

a. Dependent Variable: Continuance Commitment 
Continuance Commitment was entered as dependent variable and Competency Development Practices as Independent variable in Model 3. The outcome of HO3: was that 'Competency development Practices' does indeed have a significant role in achieving Continuance Commitment but the value of beta is very low i.e. 0.184 which means only $18.4 \%$ continuance commitment is defined by competency development practices. The regression analysis showed that 'Competency Development Practices' to be significant at the 0.000 level, which is lower than the 0.05 confidence level of this study. This result rejects the null hypothesis, which concludes that "There is a significant role of Competency Development Practices in achieving Continuance Commitment". The finding reported by Paré G. \& Tremblay, M. (2004), they found that Competency Development Practices have a significant role in achieving Continuance Commitment. Another study conducted on doctors proved that low concern for people development and poor training climate (competency development practices) results in lower commitment, and frustration among the doctors (Maheshwari, S. et al 2007).

\section{RESULTS AND DISCUSSIONS}

Competence development was found to have a significant role in achieving all the three components of commitment. Results of this study showed that Competency Development Practices have a significant in achieving affective commitment, which is consistent with the findings of the various researchers (Zaitouni,M. et al 2011; Paré G. and Tremblay, M. 2004; Paré G. et al 2001, Colbert, A. E. \& Kwon, I. G. 2000) while this is not consistent with the work of other researchers (Sawalha, N. et al 2012). Also a significant relationship of competency development practices with normative commitment of this study is different with the work of researchers (Zaitouni,M. et al 2011; Sawalha, N. et al 2012) but it also has implications on the engineers of NCR. Competency development practices such as responsibilities as per employees' interest, coaching and training, mentoring, accessibility of resources to develop new competencies, encouragement to apply innovative work practices etc have a significant role in achieving organizational commitment of the engineers of NCR. The more the engineers of NCR perceive competency development opportunities, the more they feel committed to their organization. Moreover this study also showed a significant relationship between competency development practices and continuance commitment. This finding is consistent with the work of some researchers (Pare G. \& Tremblay, M. 2004) who showed significant relationship between competency development practices and continuance commitment while different with the findings of other researchers (Zaitouni,M. et al 2011; Sawalha, N. et al 2012) who showed that competency development practices and continuance development practices have negative and no significant role in achieving continuance commitment. But the findings of this research have a positive impact on the commitment of the engineers of NCR. Paré G. \& Tremblay, M. 2004 argued that "an organization that invests in its human capital and grants employees sufficient resources and opportunities to improve their skills (competence development), and accepts greater power-sharing in the definition, coordination and conduct of work has a greater likelihood of developing a higher level of affective commitment among its highly-skilled professionals. Such practices make the professionals feel important, responsible and free to optimally channel their creativity and competencies". The management literature growingly acknowledged the importance of competency development practices in enhancing the employees' commitment (Zaitouni, M. et al 2011; Paré, G. \& Tremblay, M. 2004; Sawalha, N. et al 2012; Paré, G. et al 2001). Another study conducted on doctors proved that low concern for people development and poor training climate (competency development practices) results in lower commitment, and frustration among the doctors (Maheshwari, S. et al 2007). So in today's work environment competency development practices have become a vital strategic management tool to enhance the commitment of employees at work place. 


\section{CONCLUSION}

Competency development practices (e.g. responsibilities as per employees' interest, coaching and training, mentoring, accessibility of resources to develop new competencies, encouragement to apply innovative work practices etc) are considered to enhance the employee commitment. Organizations that give emphasis to competency development practices such as 1) Managers usually give responsibilities to employees according to their respective background and interests, 2) Employees have the possibility to develop their skills in order to increase their chances of being promoted, 3) Several professional development activities (e.g., coaching, training) are offered to employees to improve their skills and knowledge, 4) Proficiency courses such as specialized technical courses and professional certification are encouraged by management, 5) In my work unit, it is easy to get the resources (e.g., time, financial aid, flexible schedules) necessary to acquire new competencies, 6) In my work unit, employees are encouraged to experiment and share knowledge; are able to attain employee commitment. The findings of this research have a positive impact on the commitment of the engineers of NCR. Paré G. \& Tremblay, M. 2004 argued that "an organization that invests in its human capital and grants employees sufficient resources and opportunities to improve their skills (competence development), and accepts greater power-sharing in the definition, coordination and conduct of work has a greater likelihood of developing a higher level of commitment among its highly-skilled professionals.

\section{REFERENCES}

1) Agarwal, R. and Ferratt, T. W. (1999), "Coping with Labor Scarcity in IT: Strategies and Practices for Effective Recruitment and Retention". Pinnaflex: Cincinnati, OH, 1999.

2) Allen, N. J. and Meyer, J. P. (1990), “The Measurement and Antecedents of Affective, Continuance and Normative Commitment to the Organization". Journal of Occupational
Psychology, Vol. 63, pp. 1-18.

3) Boglera, R. and Somech, A. (2004), "Influence of teacher empowerment on teachers' organizational commitment, professional commitment and organizational citizenship behavior in schools". Teaching and Teacher Education, 20, pp. 277-289.

4) Colbert, A. E. and Kwon, I. G. (2000), “Factors Related To The Organizational Commitment of College And University Auditors". Journal of Managerial Issues, Vol. 12, No. 4, pp. 484-501

5) Delamare Le Deist, F., and Winterton, J. (2005), "What is Competence"? Human Resource Development International, Vol. 8, pp. 27-46.

6) Feinstein, A. H. and Vondrasek, D. (2001), “A Study of Relationships between Job Satisfaction and Organizational Commitment among Restaurant Employees" http:/ / www.hotelnewsresource.com/article192 4feature_a_study_of_relationships_between_jo b_satisfaction_and_organizational_commitment_ among_restaurant_employees.html

7) Forrier, A., Sels, L., and Stynen, D. (2009), "Career Mobility at the Intersection between Agent and Structure: A Conceptual Model". Journal of Occupational and Organizational Psychology, Vol. 82, pp. 739-759.

8) Guptill, B. (1998), "Value in IT: Staffing Issues for 1999", Gartner Group Commentary".

9) Hassan, S. and Mahmood, B. (2016), "Relationship between HRM Practices and Organizational Commitment of Employees: An Empirical Study of Textile Sector in Pakistan". International Journal of Academic Research in Accounting, Finance and Management Sciences, Vol. 6, No.1, pp. 23-28.

10) Heinsman, H., De Hoogh, A. H. B., Koopman, P. L., and Van Muijen, J. J. (2006), “Competency Management: Balancing between Commitment and Control". Management Review, Vol. 17, No. 3, pp. 292-306.

11) Jeet, V. and Sayeeduzzafar (2014), "A Study of Human Resource Management Practices and Organizational commitment in Self-Financed Professional Institutions". International Journal 
of Advance Research in Computer Science and Management Studies, Volume 2, No. 1, pp 69-73.

12) Lawler, E. E. (1994), "From Job-Based to Competency-Based Organizations". Journal of Organizational Behavior, Vol. 15, pp. 3-15.

13) Maheshwari, S., Bhat, R. and Dhiman, A. (2007), "Implications of Human Resource Practices and Other Structural Factors on Commitment of Public Medical Professionals in India". W.P. No.2007-08-04, Indian Institute of Management Ahmedabad.

14) Meyer, J. P. and Allen, N. J. (1991), “A ThreeComponent Conceptualization of Organizational Commitment". Human Resource Management Review, Vol. 1, No. 1, pp. 61-89.

15) Meyer, J. P., and Allen, N. J. (1984), “Testing the "Side-Bet Theory" of Organizational Commitment: Some Methodological Considerations". Journal of Applied Psychology, Vol. 69, pp. 372-378.

16) Mowday, R. T., Steers, R. M. and Porter, L. W. (1979), "The Measurement of Organizational Commitment". Journal of Vocational Behaviour, Vol. 14, pp. 224-247.

17) Paré, G. And Tremblay, M. (2000), “The Measurement and Antecedents of Turnover Intentions among IT Professionals".

18) Paré, G. and Tremblay, M. (2004), “The Influence of High-Involvement Human Resources Practices, Procedural Justice, Organizational Commitment and Citizenship Behaviors on Information Technology Professionals' Turnover Intentions". Cahier du GReSI no 04-17.

19) Paré, G., Tremblay, M., and Lalonde, P. (2001), "The Role of Organizational Commitment and Citizenship Behaviors in Understanding Relations between Human Resources Practices and Turnover Intentions of IT Personnel". Cahier du GReSI no 01-07.

20) Sawalha, N., Zaitouni, M., and Sharif, A. (2012), “Corporate Culture Dimensions Associated With Organizational Commitment: An Empirical Study". The Journal of Applied Business Research, Vol. 28, No. 5, pp 957-976.

21) Schwochau, S., Delaney, J., Jarley, P., and Fiorito,
J. (1997), “Employee Participation and Assessments of Support for Organizational Policy Changes". Journal of Labour Research, Vol. 18, No. 3, pp. 379-401.

22) Shahnawaz, M.G. and Juyal, R. C. (2006), "Human Resource Management Practices and Organizational Commitment in Different Organizations". Journal of the Indian Academy of Applied Psychology, Vol. 32, No. 3, pp. 171178.

23) Soltani, M. (2015), “Organizational Commitment and HRM Practices: An Analytical Approach". Global Journal of Advance Research, Vol-2, No. 9, pp 1465-1472.

24) Spencer, L. M., and Spencer, S. M. (1993), "Competence at Work: Models for Superior Performance". New York: John Wiley.

25) Steers, R. M. (1977), “Antecedents and outcomes of organizational commitment". Administrative Science Quarterly, Vol. 22, No. 1, pp. 46-56.

26) Tampoe, M. (1994), Exploiting the Core Competencies of Your Organization. Long Range Planning, Vol. 27, No. 4, pp. 66-77

27) Tsui, A. S., Pearce, J. L., Porter, L. W., and Hite, J. P. (1995), “Choice of Employee-Organization Relationship: Influence of External and Internal Organizational Factors", In G.R Ferris (ed.) Research In Personnel and Human Resource Management, Greewich, CT: JAI Press, pp.117151.

28) Van der Klink, M. R., and Boon, J. (2003), "Competencies: The Triumph of a Fuzzy Concept". International Journal of Human Resources Development and Management, Vol. 3, pp. 125-137.

29) Zaitouni, M., Sawalha, N. N., and Sharif, A. (2011), "The Impact of Human Resource Management Practices on Organizational Commitment in the Banking Sector in Kuwait". International Journal of Business and Management, Vol. 6, No. 6, pp 108-123. 